\title{
a \\ THE \\ Assessing the Vulnerability of a Municipal Well Field to Contamination in a Karst Aquifer
}

GEOLOGICAL

SOCIETY

OF AMERICA

\author{
R. A. RENKEN
}

K. J. CUNNINGHAM

M. R. ZYGNERSKI

M. A. WACKER

U.S. Geological Survey, 3110 SW 9th Avenue, Fort Lauderdale, FL 33315

A. M. SHAPIRO

U.S. Geological Survey, 12201 Sunrise Valley Drive, MS 431, Reston, VA 20192

R. W. HARVEY

D. W. METGE

U.S. Geological Survey, 3215 Marine Street, Suite E-127, Boulder, CO 80303

\author{
C. L. OSBORN
}

J. N. RYAN

University of Colorado, 1111 Engineering Drive, ECOT 511, Boulder, CO 80309

Key Terms: Karst Aquifers, Ground-Water Tracers, Pathogens, Well Field Protection

\begin{abstract}
Proposed expansion of extractive lime-rock mines near the Miami-Dade County Northwest well field and Everglades wetland areas has garnered intense scrutiny by government, public, environmental stakeholders, and the media because of concern that mining will increase the risk of pathogen contamination. Rock mines are excavated to the same depth as the well field's primary producing zone. The underlying karst Biscayne aquifer is a triple-porosity system characterized by (1) a matrix of interparticle porosity and separate vug porosity; (2) touching-vug porosity that forms preferred, stratiform passageways; and, less commonly, (3) conduit porosity formed by thin

Disclaimer: The use of brand names in this paper is for identification purposes only and does not constitute endorsement by the authors, the U.S. Geological Survey, or Environmental \& Engineering Geoscience.
\end{abstract}

solution pipes, bedding-plane vugs, and cavernous vugs. Existing ground-water flow and particle tracking models do not provide adequate information regarding the ability of the aquifer to limit the advective movement of pathogens and other contaminants. Chemical transport and colloidal mobility properties have been delineated using conservative and microsphere-surrogate tracers for Cryptosporidium parvum. Forced-gradient tests were executed by introducing conservative tracers into injection wells located $100 \mathrm{~m}(328 \mathrm{ft})$ from a municipal-supply well. Apparent mean advective velocity between the wells is one to two orders of magnitude greater than previously measured. Touching-vug, stratiform flow zones are efficient pathways for tracer movement at the well field. The effective porosity for a continuum model between the point of injection and tracer recovery ranges from 2 to 4 percent and is an order of magnitude smaller than previously assumed. Existing well-field protection zones were established using porosity estimates based on specific yield. The effective, or kinematic, porosity of a Biscayne aquifer continuum model is lower than the total porosity, because high velocities occur along preferential flow paths that result in faster times of travel than 
Renken, Shapiro, Cunningham, Harvey, Metge, Zygnerski, Osborn, Wacker, and Ryan

can be represented with the ground-water flow equation. Tracer tests indicate that the relative ease of contaminant movement to municipal supply wells is much greater than previously considered.

\section{INTRODUCTION}

Florida's largest municipal well field, the Northwest well field in north-central Miami-Dade County, is contained within a marginal wetland area (Figure 1). The well field is located on the eastern edge of a $231-\mathrm{km}^{2}$ $\left(89-\mathrm{mi}^{2}\right)$ Lake Belt "mining district" area that buffers intensively developed urban areas from critical ecosystems and wetland areas of the Florida Everglades to the west. The highly transmissive Biscayne aquifer underlies the well field and has been designated a sole source of potable water by the U.S. Environmental Protection Agency (U.S. EPA) (Federal Register Notice, 1979).

South Florida's extractive limestone mine industry is permitted, by regulatory authority of the U.S. Army Corps of Engineers, to remove limestone rock on adjacent, private land. Extraction activities are creating borrow-pit "lakes" that are up to 12-18 m (40-60 ft) deep, some of which will be in close proximity to the 60-day well-field production zone. There is concern that municipal supply wells will be directly influenced by the quality of surface water contained within these mines if excavation near the Northwest well field continues as planned. Some existing borrow-pit lakes are within $247 \mathrm{~m}$ (810 ft) of production wells (Figure 2).

The U.S. EPA requires use of enhanced disinfection and filtration treatment processes to remove pathogenic organisms if ground-water withdrawals from municipal well fields are determined to be under the direct influence of surface water (Federal Register Notice, 2000). Microbial contamination of ground water is a serious public health concern and the cause for more than half of the Nation's waterborne disease outbreaks (Macler and Merkle, 2002).

The U.S. Geological Survey, in cooperation with the Miami-Dade Department of Environmental Resources Management, Miami-Dade Water and Sewer Department, and the American Water Works Research Foundation, have engaged in an integrated study to (1) assess transport of solute contaminants and pathogenic protozoa within a highly permeable, karstic limestone aquifer and (2) examine the importance of straining or other filtration mechanisms that may or may not impede microbial advective movement. This article outlines project objectives, discusses the status of laboratory and field activities, and examines well-field vulnerability-assessment issues that pertain to the Biscayne aquifer in north-central Miami-Dade County, Florida.

Fifteen municipal water-supply wells compose the Northwest well field, with an approximate combined permitted capacity of $587,740 \mathrm{~m}^{3} /$ day $(155 \mathrm{Mgal} /$ day $)$ and a planned capacity of $851,700 \mathrm{~m}^{3} /$ day ( $225 \mathrm{Mgal} /$ day). In 2003 , daily withdrawals averaged about $242,300 \mathrm{~m}^{3} /$ day (64 Mgal/day). Regional ground-water movement is eastward from the Everglades and Pennsuco wetland areas (Figure 1). Conveyance canals that border the well field in all directions help to recharge it. The eastern canal is designed to maintain stage levels that limit eastward expansion of the cone of depression during the dry season. Cone enlargement into urban areas could increase the risk of well-field contamination (Walters, 1987).

\section{VULNERABILITY-ASSESSMENT UNCERTAINTIES IN THE NORTHWEST WELL FIELD}

Process-based vulnerability assessments generally contain two principal sources of uncertainty (National Research Council, 1993). One source of uncertainty is associated with application of numerical or analytical models that are not well suited to address physical system complexities. Miami-Dade County has used ground-water flow and particle-tracking models to identify flow path lines and to define time-of-travel protection zones (Camp, Dresser, and McKee, Inc., 1982, 1985; CH2M HILL, 2001). However, there is an important limitation in an equivalent continuum model when it is applied to tripleporosity aquifers (principally matrix and touching-vug porosity with rare conduit porosity visible in the Northwest well field based on digital borehole images). For example, an inherent assumption with a finite-difference ground-water flow model is that the aquifer can be treated as an equivalent porous medium; namely, the aquifer is formed of porous material, in which void space is uniformly distributed. Additionally, the equation assumes laminar flow, which may not be the case in conduits that may behave as pipes or open channels. Therefore, the conventional ground-water flow equation may not be valid for the Biscayne aquifer's entire flow domain.

Equivalent continuum, single-porosity models do provide reasonable volume-averaged approximations of large-scale ground-water flow (National Research Council, 1996). Under the continuum approach, however, the heterogeneity of a generalized karst-aquifer conceptual model is highly simplified, even though it may be characterized by high-velocity, turbulent ground-water flow within solution-enhanced fractures, conduits, or stratiform passageways. Near- and very near-field conditions may be poorly represented in the continuum approach (Cacas et al., 1990a, 1990b; Bear, 1993), and patterns of simulated flow and particle movement are marked by latent uncertainty (Anderson and Woessner, 1992).

The second source of uncertainty is associated with the quality and spatio-temporal relevance of data that are available to quantify vulnerability. Preexisting field data may not necessarily provide the physical parameters best 


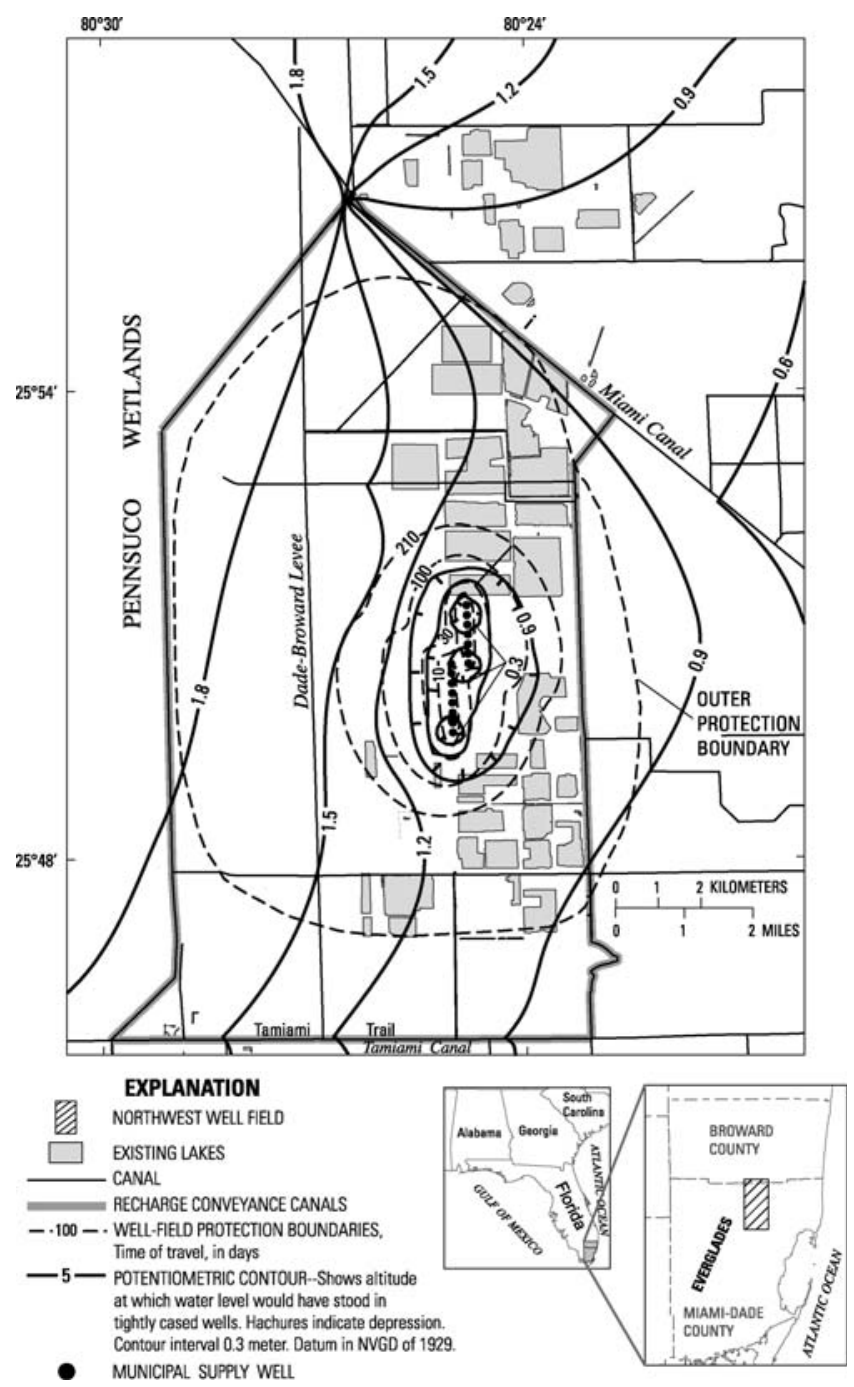

Figure 1. Location of the Northwest well field, the potentiometric surface on April 22, 2003, and existing well-field protection boundaries in north-central Miami-Dade County.

suited to assess the risk of contamination. Critical data gaps may exist that cannot be resolved except through labor-intensive data acquisition. Hydraulic parameters may have been obtained as part of a separate, unrelated investigation with different objectives or needs; for example, cyclic water-table fluctuations near tidal canals have been used to determine Biscayne aquifer hydraulic properties, but represent conditions only within the uppermost part of the aquifer penetrated by the depth of the canal (Fish and Stewart, 1991). Hydraulic parameters may have been determined through other indirect methods, including model calibration and verification. Similarly, estimates of aquifer porosity may be determined by visual examination, laboratory measurements of core samples, or indirectly use of borehole geophysical tools; however, those estimates can differ considerably from the effective porosity used in continuum models.
Even the judicious application of process-based methods to assess movement and fate of contaminants may not necessarily offer a reliable denouement (National Research Council, 1993, p. 6). Therefore, the recognition of inherent model- and data-related uncertainties becomes a critical element in any municipal well-field vulnerability assessment. Incorporation of such irresolution becomes a necessary factor for consideration in preparation of a coordinated water-resource and land-use policy.

The Northwest well-field protection zone was established in 1981 and was based, in part, on an existing (1970's) understanding of bacterial transport rates and rates of viral die-off in soils and ground water (Metropolitan Dade County, 1980, 1981). A numerical ground-water flow model was used to simulate flow under existing permitted withdrawal rates $\left(568,700 \mathrm{ft}^{3} /\right.$ day or $150 \mathrm{Mgal} /$ day) and to define time-of-travel protection zones (Prickett and Lonnquist, 1971; Camp, Dresser, and McKee, Inc., 1982, 1985). Time-of-travel well-field protection zones have been used to regulate land use and to limit activities that could adversely affect the ambient quality of ground water near the Northwest well field. Although limestone extraction activities are permitted within the protection zone, Miami-Dade County established regulatory "setback distances," thus limiting the depth of mines within 30- and 60-day time-of-travel zone areas (Metropolitan Dade County, 1983, 1985a, 1985b). A rock-mine setback distance refers to the minimum horizontal distance allowed between an extractive mine and a municipal production well. This requirement was established as the result of the realization that lime-rock mines excavated to the same depth as the major production zone increased contamination risks.

In 1996, Krupa and others (2001) performed horizontal flow-meter tests within the Northwest well-field protection area in selected observation wells that were 518-853 m (1,700-2,800 ft) from active production wells (Table 1). These tests were conducted to verify the simulated advective movement of ground water. Under well-field operational conditions on April 8-9, 1996, the velocity of ground water within the protection area is reported to have ranged between 0.52 and $4.8 \mathrm{~m} /$ day $(1.7$ and $16 \mathrm{ft} /$ day, respectively) (Krupa et al., 2001). These velocity measurements, however, likely represent a low baseline estimate, largely owing to uncertainties associated with the observation well construction and screen interval placement (Krupa, 2005). These deficiencies also should be considered in the general context of horizontal flow-meter measurement uncertainties, even under more "ideal" circumstances (Wilson et al., 2001).

The Miami-Dade County Department of Environmental Resources Management (1999, 2000a) has conducted a series of traces, injecting fluorescent dye in selected wells at various distances from pumping supply wells (Table 1). In 1998, fluorescent dye was injected into wells 


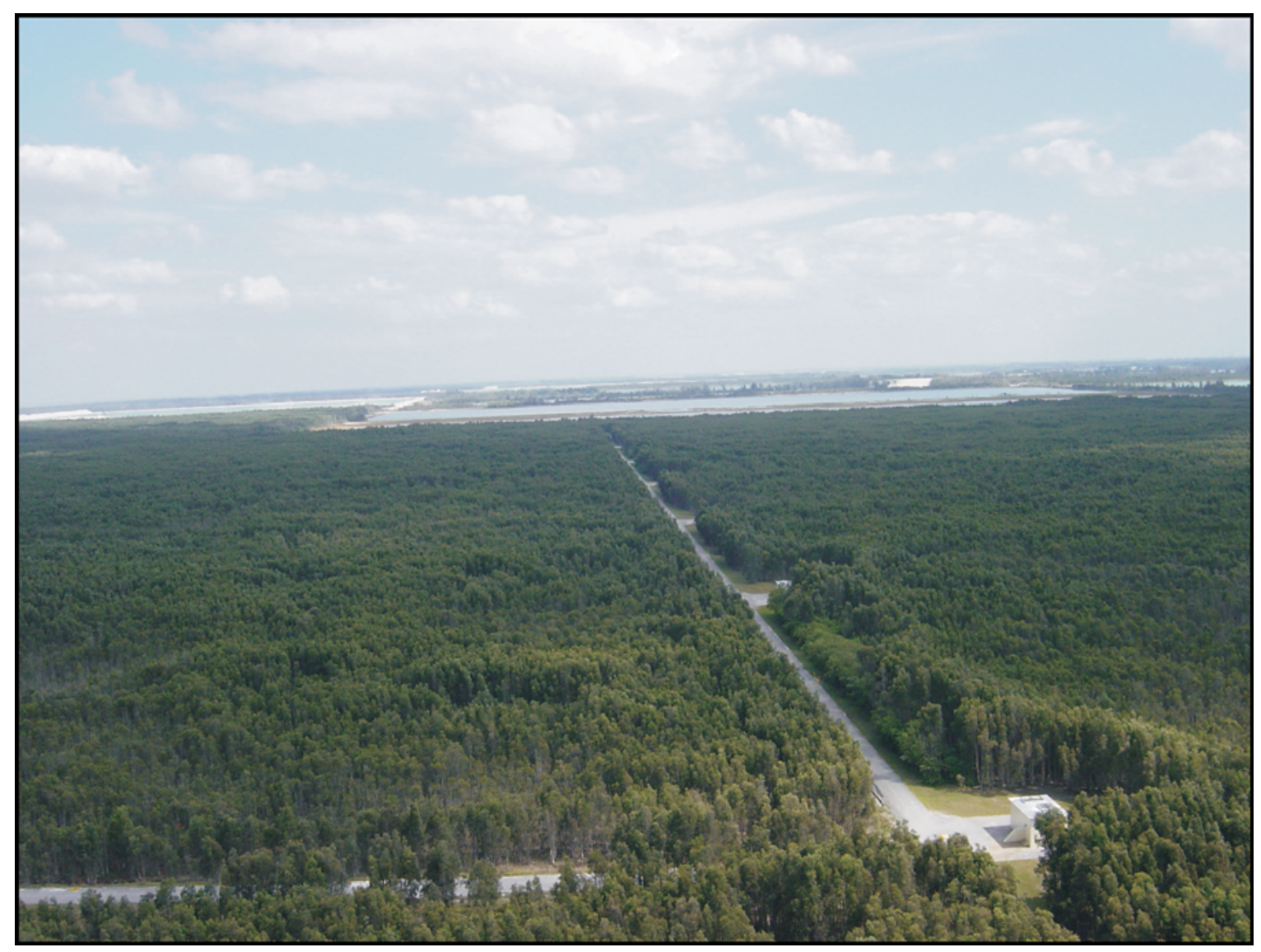

Figure 2. North-facing oblique aerial photo showing a partial view of well field and active rock-mine lakes north of production well 15 . Production well 9 pump house (S-3164) is visible near the lower right corner (photo taken by Shane Ploos, U.S. Geological Survey, April 2004).

located $257 \mathrm{~m}(845 \mathrm{ft})$ east of production well S-3163, $272 \mathrm{~m}(894 \mathrm{ft})$ east of production well S-3164, and $558 \mathrm{~m}$ $(1,830 \mathrm{ft}$ ) east of production well S-3164 (Miami-Dade Department of Environmental Resources Management, 1999). Mean velocity of the tracer pulse is reported to have ranged from 21.5 to $27.6 \mathrm{~m} /$ day $(70.5-90.6 \mathrm{ft} /$ day $)$ in short-distance traces, but dye was not detected at production well S-3164 in traces conducted over distances that exceeded $272 \mathrm{~m}$ (894 ft). In 1999, fluorescein and rhodamine WT dye were introduced into injection wells located $926 \mathrm{~m}(3,040 \mathrm{ft})$ east of the S-3164 production well (Guha et al., 2003). Dye was recovered in observation wells located $552-768 \mathrm{~m}(1,810-2,520 \mathrm{ft})$ east of well S-3164, but could not be detected in this production well (Kottke and Harrison, 2005). The mean advective velocity was reported to range from about 1.04 to $2.9 \mathrm{~m} /$ day, or 3.4 to $9.4 \mathrm{ft} /$ day (Guha et al., 2003). The 1999 tracer experiments were considered inconclusive because of poor mass recovery, variable wet- and dryseason climatic conditions that affected the hydraulic gradient, tracer dilution within the aquifer caused by downward seepage of surface water, and a poor understanding of continuity of ground-water flow zones (Guha et al., 2003). Well design and construction uncertainties (as previously outlined) also applied to the outcomes of the 1998 and the 1999 tracer tests.

To minimize public exposure under future withdrawal rates and land-use scenarios, Miami-Dade County is reviewing rock-mine setback distances that achieve a 3.5to 4.5-log (logarithmic) reduction in concentration of the pathogen Cryptosporidium parvum. An approach is being considered that evaluates pathogen removal by filtration, rate of pathogen die-off (Walker and Steninger, 1999), simulated ground-water flow patterns, and time-of-travel estimates (CH2M-HILL, 2001; Miami-Dade Department of Environmental Resources Management, 2000b). Log reduction is the terminology used to describe a reduction in the abundance of pathogens by sorptive filtration, straining, die-off, and inactivation. This reduction refers to the factors of 10 by which the number of viable pathogens are reduced. For example, a 4-log reduction of Cryptosporidium parvum corresponds to a 99.99 percent reduction in the viable numbers or inactivation and (or) removal of all but 10 of 100,000 viable öocysts. At present, this new method conservatively assumes little or no mechanical or absorptive filtration of Cryptosporidium 
Vulnerability to Contamination in a Karst Aquifer

Table 1. Estimated mean tracer velocity and horizontal flow-meter velocity under pumping well field operational conditions.

\begin{tabular}{|c|c|c|c|c|}
\hline Test & Release Date & $\begin{array}{l}\text { Distance to } \\
\text { Production Well }\end{array}$ & Mean Velocity & Citation \\
\hline Horizontal flow meter & $4 / 8 / 96-4 / 9 / 96^{1}$ & $\begin{array}{l}518-853 \mathrm{~m} \\
\quad(1,700-2,800 \mathrm{ft})\end{array}$ & $\begin{array}{l}0.52-4.76 \mathrm{~m} / \text { day } \\
\quad(1.70-15.62 \mathrm{ft} / \text { day })\end{array}$ & Krupa et al., 2001 \\
\hline $\begin{array}{l}\text { Conservative tracers rhodamine } \\
\text { WT and fluorescein (three } \\
\text { traces) }\end{array}$ & $1 / 28 / 98-12 / 17 / 98$ & $\begin{array}{l}257-849 \mathrm{~m} \\
\quad(845-1,830 \mathrm{ft})^{2}\end{array}$ & $\begin{array}{l}21.5-27.6 \mathrm{~m} / \text { day } \\
\quad(70.5-90.6 \mathrm{ft} / \text { day })\end{array}$ & $\begin{array}{l}\text { Miami-Dade } \\
\text { Department of Environmental } \\
\text { Resources Management, } 1999\end{array}$ \\
\hline $\begin{array}{l}\text { Conservative tracers rhodamine } \\
\text { WT and fluorescein }\end{array}$ & 9/10/99 & $926 \mathrm{~m}(3,040 \mathrm{ft})^{3}$ & $\begin{array}{l}1.04-2.86 \mathrm{~m} / \text { day } \\
(3.4-9.4 \mathrm{ft} / \text { day })\end{array}$ & Guha et al., 2003 \\
\hline $\begin{array}{l}\text { Conservative tracer rhodamine } \\
\text { WT and deuterium }\end{array}$ & $4 / 22 / 03$ & $100 \mathrm{~m}(328 \mathrm{~m})$ & $\begin{array}{l}386 \mathrm{~m} / \text { day } \\
\quad(1,266 \mathrm{ft} / \text { day })\end{array}$ & This report \\
\hline
\end{tabular}

${ }^{1}$ Twenty-three velocity measurements were obtained using a horizontal flow meter in eight observation wells.

${ }^{2}$ Not detected in wells located more than $272 \mathrm{~m}(894 \mathrm{ft})$ from the point of injection.

${ }^{3}$ Detected only in observation wells, not in the S-3164 supply well.

parvum, because it is not known if mechanical filtration (settling and attachment) can attenuate microbial transport in the Biscayne aquifer. Unlike granular media, in which processes of colloidal filtration have been documented and analytically formulated (Harvey and Garabedian, 1991), the efficacy of solution-enhanced limestone to impede subsurface movement of protozoa has not been previously determined (Osborn et al., 2004).

\section{ASSESSING POTENTIAL FOR GROUND-WATER PATHOGEN TRANSPORT}

Pathogens cannot be introduced into a ground-water system to assess their potential for transport; instead, alternative investigations and proxies for ground-water pathogens must be used. In this study, a coupled laboratory and field investigative strategy was employed to assess Biscayne aquifer pathogen transport potential. Laboratory static- and flow-through column tests were performed to determine if equivalently sized colloidal particles (carboxylated polystyrene microspheres) function as a viable surrogate for the Cryptosporidium parvum pathogen. A geologic site investigation was conducted in conjunction with hydraulic tests to characterize preferential pathways for ground-water flow. Three field tracer tests were performed between April 2003 and March 2004 using a suite of conservative tracers-fluorescent dye, bromide, deuterium $\left({ }^{2} \mathrm{H}\right)$, dissolved gas including halon $1211\left(\mathrm{CBrClF}_{2}\right)$ and sulfur hexafluoride $\left(\mathrm{SF}_{6}\right)$, and the microspheres.

\subsection{Laboratory Column Studies}

Column study experiments using Cryptosporidium parvum (Sterling Parasitology Laboratory, University of Arizona, Tucson, AZ) and carboxylated polystyrene microspheres (Polysciences, Inc., Warrington, PA) were designed to assess physicochemical properties, attach- ment behavior, and transport within the Biscayne aquifer under controlled laboratory conditions. Experiments using partially crushed limestone rock within a saturated column of static artificial ground water comparable to ambient well-field conditions were used to assess the effect of calcium-bicarbonate water, dissolved organic carbon, $\mathrm{pH}$, and ionic strength. These vertical saturated column property tests indicate that physicochemical properties of $\sim 2-, \sim 3-$, and $\sim 5-\mu \mathrm{m}$ size microspheres compare favorably with Cryptosporidium parvum and, therefore, could be used as an applicable proxy (Osborn et al., 2004). Analysis of flow-through column experiments using intact whole-core samples of representative lithofacies that compose the aquifer is underway. This evaluation is expected to provide additional insight regarding vertical and horizontal pathogen movement within the internal rock fabric of the aquifer.

\subsection{Hydrogeologic Characterization}

Karst aquifers are traditionally characterized by interparticle matrix porosity, fracture porosity, and large cavernous porosity (Martin and Screaton, 2001). This has led many to view karst aquifers as two-component systems, in which much of the ground-water storage occurs in the matrix porosity or fractures or both and in which transport of ground water takes place in the large dissolution conduits (cf. Martin and Screaton, 2001). In the young eogenetic karst that defines the Pleistocene limestone of the Biscayne aquifer, however, touching-vug porosity is especially important in terms of conveyance of ground water (Vacher and Mylroie, 2002; Cunningham et al., 2006). The karstic Biscayne aquifer is a tripleporosity system that is mostly characterized by (1) a matrix of interparticle porosity and separate vugs, (2) stratiform preferred ground-water passageways formed by touching vugs (Lucia, 1995, p. 1260, 1999), and (3) less common conduit porosity composed mainly of bedding-plane vugs, thin solution pipes, and cavernous 
vugs. Touching-vug pore space is pore space formed by vugs that coalesce as an interconnected pore system of significant extent. Stratiform refers to the three-dimensional aspects of the porosity; that is, it is constrained to a layer, bed, or stratum with lateral continuity (Jackson, 1997). Cunningham and others (2004b, 2004c, 2006) have developed a conceptual model of the hydrogeology of the Biscayne aquifer in the Lake Belt area in which they have delineated, classified, and mapped the aquifer's internal pore system.

A high-resolution hydrogeologic framework was mapped within the Northwest well field, demonstrating the utility of carbonate cyclostratigraphic concepts for predicting the spatial distribution of preferred groundwater flow zones within the eogenetic karst Biscayne aquifer (Cunningham et al., 2006). The cyclostratigraphy presented herein divides fundamental depositional cycles (high-frequency cycles) into units defined by distinct vertical lithofacies successions bounded by surfaces across, in which there is evidence for a relative increase in ancient sea level (cf. Kerans and Tinker, 1997). The vertical and lateral distribution of mapped high-frequency cycles (HFCs) in the Northwest well field is shown in Figure 3.

Movement of ground water within water-bearing strata of the Biscayne aquifer occurs within pore classes I, II, and III (Table 2 and Figure 3). Each pore class comprises a unique category of lithofacies and pore systems (Cunningham et al., 2006). Carbonate-rock lithofacies and pore systems can be arranged within the context of high-frequency carbonate cyclostratigraphy. The porosity of pore class I typically is characterized by touching-vug and conduit porosity. Pore class II is distinguished by matrix porosity. The porosity of pore class III typically is separate vugs within a very low-permeability micrite (mud-sized limestone) matrix that may be perforated by small semivertical solution pipes of limited vertical extent or may have associated bedding plane vugs. The overall permeability of pore class III is commonly low, but leaky. The distribution of these three pore classes occurs within vertical and horizontal spatial patterns because their manifestation is directly related to the vertical assemblage of lithofacies within high-frequency cycles (Cunningham et al., 2006). Whole-core and digital borehole-image log data have been used to quantify Biscayne aquifer porosity within the well field using the methods described in Cunningham and others (2004a). Interval vuggy porosity values for slabbed whole-core samples from highfrequency limestone cycles in the Lake Belt area can range from less than 1 to 41.4 percent (Cunningham et al., 2004a), but characterization of porosity specific to different facies or pore-system flow class was not conducted.

Three injection wells (G-3773, G-3816, and G-3817) and one observation well (G-3772) were drilled as part of the field investigation (Figure 3) and showed correlative geologic and hydrogeologic relations within the well field. On the basis of descriptive core analyses, borehole data (geophysical, optical image, and flow-meter profiles), and aquifer performance tests, touching-vug zones dominate the lower part of the Biscayne aquifer from an altitude of -8.5 to $-20.5 \mathrm{~m}$ ( -28 to $-67 \mathrm{ft}$ ) (Figure 3).

Borehole flow profiles of tracer injection wells using a Century Geophysics ${ }^{\mathrm{TM}}$ electromagnetic flow meter (Tulsa, OK) were performed to identify prospective high-permeability flow zones and to qualitatively assess borehole formation properties. Single-well and crossborehole flow-meter tests were conducted to assess the continuity and interconnection of flow zones between the injection wells G-3773, G-3816, and G-3817 and the S-3164 production well during ambient and short-term stress conditions. Profiles indicated that substantial loss of vertical bore flow occurred within all three flow zones; therefore, they were considered to be important highpermeability ground-water flow pathways. Ground-water flow zones identified within high-frequency cycles HFC 2a, HFC $2 b$, and HFC 2e 2 were selected for further field analysis (Figure 3).

\subsection{Hydraulic Test Activities}

Aquifer performance tests were conducted at production well S-3164 in the center of the Northwest well field and were performed in conjunction with controlled, forced-gradient tracer tests during April 2003 and February and March 2004. Withdrawals within the entire well field were highly regulated during test activities, and drawdown measurements were collected at observation wells located $10-2,590 \mathrm{~m}(33-8,500 \mathrm{ft})$ from the production well. The Biscayne aquifer is highly transmissive, with values reportedly ranging from 102,230 to $269,410 \mathrm{~m}^{2} /$ day $\left(1,100,000-2,900,000 \mathrm{ft}^{2} /\right.$ day $)$ near the Northwest well field (Fish and Stewart, 1991).

Traditionally, the Biscayne has been described as an unconfined aquifer (Parker et al., 1955; Fish and Stewart, 1991). Permeable ground-water flow zones within the Biscayne aquifer, however, appear to be semiconfined in an area southwest of the Northwest well field (Cunningham et al., 2004c). In north-central MiamiDade County, the change in hydraulic head in response to hydrologic stress (withdrawals, precipitation, and canal stage) in more deeply buried water-bearing strata usually mirrors those fluctuations that occur at the water table. Conversely, semiconfined hydrologic conditions within the well field are implied by the occurrence of a lowamplitude $(0.003-\mathrm{m}$ or $0.010-\mathrm{ft})$ diurnal change in water levels observed during both pumping and nonpumping well-field operation. Harmonic water-level change is commonly observed within coastal confined or semiconfined aquifers that are subject to mechanical (tidal) or 
Vulnerability to Contamination in a Karst Aquifer

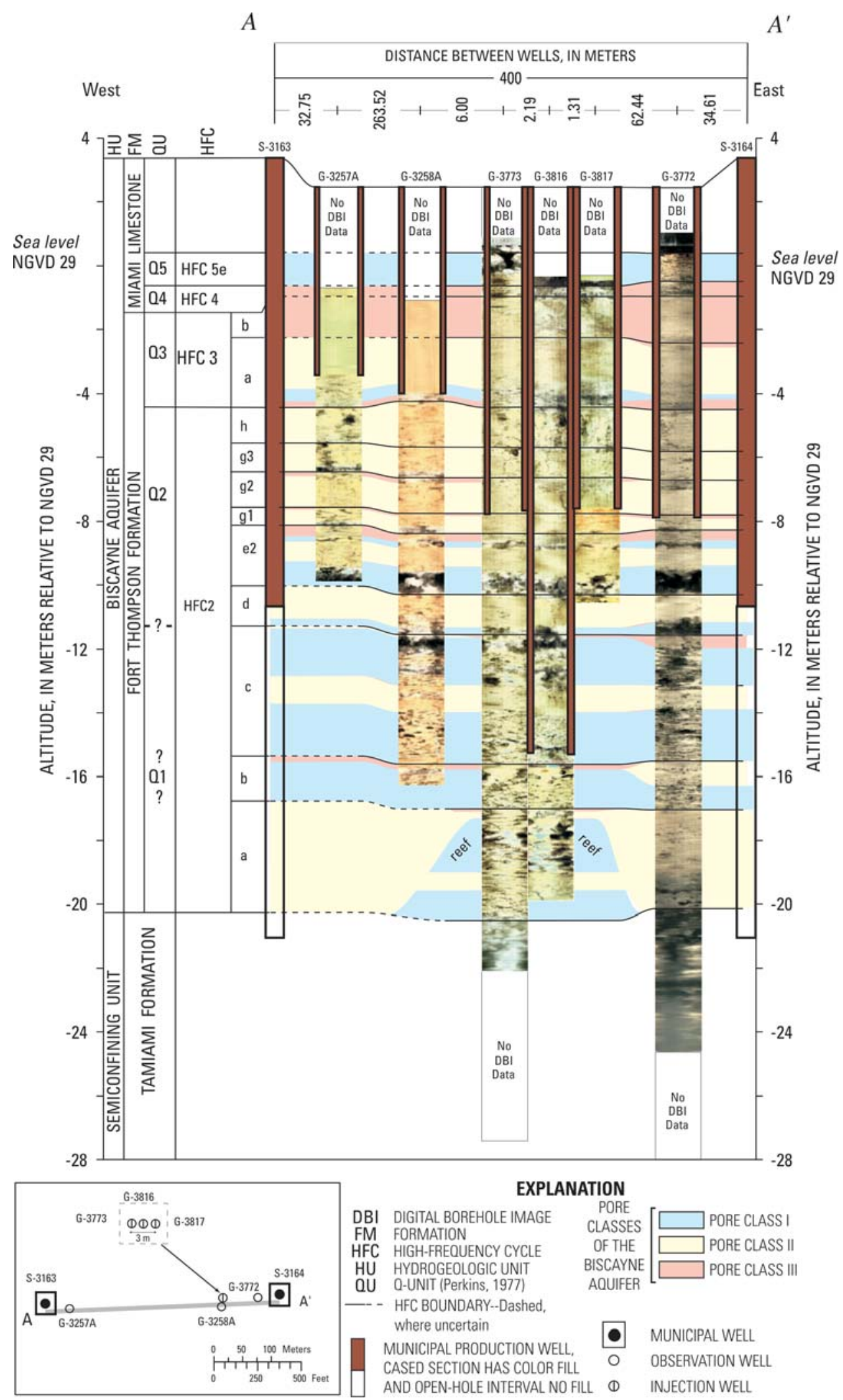

Figure 3. Line of section between S-3163 and S-3164 showing optical borehole image logs, relation between sequence stratigraphic units, and classification of ground-water flow within the Northwest well field. 
Table 2. Pore classes (I, II, III) related to aquifer attributes at the Northwest Well Field.

\begin{tabular}{lcc}
\hline \hline Pore Class & Major Pore Type & $\begin{array}{c}\text { Major Type of } \\
\text { Ground-Water Flow and } \\
\text { Relative Permeability }\end{array}$ \\
\hline III & $\begin{array}{c}\text { Separate vugs, including } \\
\text { moldic and thin vertical } \\
\text { solution pipes }\end{array}$ & $\begin{array}{c}\text { Leaky (limited small-scale } \\
\text { conduit flow), typically } \\
\text { low permeability } \\
\text { II }\end{array}$ \\
I & $\begin{array}{c}\text { Interparticle porosity and } \\
\text { separate vugs } \\
\text { Touching vugs, including } \\
\text { solution-enlarged molds } \\
\text { of fossils, burrows, and } \\
\text { roots; interburrow and } \\
\text { inter-root vugs; and } \\
\text { uncommon bedding plane }\end{array}$ & $\begin{array}{c}\text { Conduit flow, high } \\
\text { permeability }\end{array}$ \\
& vugs and cavernous vugs & \\
\hline
\end{tabular}

pressure-forcing (barometric) influences. The effect of unconfined storage dampens water-table harmonic oscillations within several hundred meters of the coastline (Erskine, 1991). Specific mechanisms that control these low-amplitude fluctuations, including the possible effect of shallow water-table wetland evapotranspiration, have not been resolved.

A high-frequency, early-time, oscillatory hydraulic response was observed during the first minute of the aquifer test and was considered indicative of high transmissivity. A similar underdamped hydraulic response has been reported elsewhere in highly transmissive, fracturedrock carbonate aquifers, including the Floridan aquifer system and the Silurian dolomite in northeastern Illinois (Bredehoeft et al., 1966; Giffin and Ward, 1989; and Shapiro, 1989). Sensitivity of the Biscayne aquifer to hydrologic stress was exhibited during the course of the aquifer test, as demonstrated by the rapid change in ground-water levels in response to precipitation and canal stage. Canals represent important hydrologic boundaries, despite well-to-canal separation distances of 2.4 to $3.2 \mathrm{~km}(1.5-2.0 \mathrm{mi})$.

In southern Florida, effective or kinematic porosity of the Biscayne aquifer has been assumed to be approximately equivalent to specific yield by some researchers (Merritt, 1996, p. 46). Lohman (1972) defines effective porosity as a measure of the interconnected pore space available for the transmission of ground water. Kinematic porosity is defined as voids in pore space occupied by moving water relative to the total rock volume (de Marsily, 1986). Specific yield is the ratio of water drained by gravity from an aquifer to the total volume of the aquifer. The specific yield of the Biscayne aquifer is reported to range from 10 to 35 percent (Schroeder et al., 1958). Treating specific yield as an "equivalent" measure may be viewed as a reasonable assumption in granular media that lack isolated and dead-end (cul de sac) pore space, are not affected by capillary tension, and are not affected by the length of time provided for gravity drainage to occur. This equivalency premise does not consider a more complex condition that may occur, in which system porosity is divided into a dual-domain set of mobile and immobile parameters (van Genuchten and Wierenga, 1976; Reeves et al., 1991).

A detailed description of the spatial distribution of aquifer porosity is rarely available. Most commonly, a uniform distribution of porosity within the model domain is assumed. For example, a constant 20 percent specific yield has been applied to the uppermost layer of the model layer in north Miami-Dade County (Wilsnack et al., 2000) and in Northwest well-field ground-water flow models (CH2M-HILL, 2001). Backward-tracked flow pathlines were defined, assuming that the porosity of the Biscayne aquifer is 20 percent and uniformly distributed (CH2M-HILL, 2001; Guha, 2005). Groundwater flow in the Biscayne aquifer is broadly controlled by hydraulic gradient; however, preferential, high-velocity flow paths are likely constrained to the interconnected part of the pore system. For example, two equal-volume blocks of an aquifer, with equivalent permeability and boundary stresses, may have similar bulk porosity but different effective porosity. The volume of aquifer with a smaller effective porosity will transmit water at a higher velocity. Conversely, the volume of aquifer with larger effective porosity will transmit water at lower velocities. Biscayne aquifer equivalency assumptions for effective porosity and specific yield indicate that it is reasonable to anticipate differences between measured and simulated ground-water velocity.

\subsection{Conservative and Colloidal Tracer Tests}

A conservative tracer test was performed in April 2003 to obtain data on formation properties and transport parameters and to aid in the design of a particulate-tracer experiment. A forced-gradient tracer test was executed using a 50-kg (110-lb) mass of rhodamine WT (Liquid Acid Red 388 dye; Keystone Aniline Corporation, Chicago, IL) and a $15-\mathrm{kg}$ (33-lb) mass of deuterium $\left({ }^{2} \mathrm{H}\right.$; Cambridge Isotope Laboratories, Andover, MA) (Table 1). A centrifugal pump was used to introduce tracer material into the injection well, G-3773, which was completed as an open borehole from approximately $-7.7 \mathrm{~m}$ to $-20.5 \mathrm{~m}(-25$ to $-67.3 \mathrm{ft})$ below sea level. A pipe extended from the pump into the borehole, with its opening located at the same depth as the flow zone, HFC 2e2 (Figure 4). Injection well G-3773 is located $100 \mathrm{~m}$ $(328 \mathrm{ft})$ west of the production well, S-3164, which discharged at an average rate of $0.49 \mathrm{~m}^{3} /$ second $(7,900$ gpm). Following injection, gravity-fed formation water was used to flush the two conservative tracers from the borehole into the Biscayne aquifer. Borehole water 
samples were collected at both the production and injection wells to assess tracer movement within the formation.

Peak tracer pulse breakthrough occurred in 6.5 hours (Figure 4). Between the point of injection and the production well, the apparent mean advective flow velocity observed during this test appears to be one to two orders of magnitude greater than previously measured (Table 1). Recovery of rhodamine WT is estimated to have been about 60 percent of the injected mass at the time the test was prematurely terminated at 12.75 hours. Comparison of mean tracer velocity during this test with previous determinations is not possible, however, because of differences in (1) test objectives, (2) distance and location of the point of injection and tracer recovery (production) well, (3) hydrologic conditions (hydraulic gradient, well-field operation, canal stage levels, and climate), (4) injection- and observation-well construction uncertainty, and (5) uncertainty regarding the geologic character of ground-water flow zones previously tested.

Horizontal flow-meter measurements and dye traces conducted previously (Miami-Dade Department of Environmental Resources Management, 1999, 2000a; Krupa et al., 2001; and Guha et al., 2003) were designed to assess the potential for contamination from existing borrow-pit lakes located, in a regional sense, downgradient of the supply wells. Tracer tests conducted during the present study were designed, in part, to also consider the potential adverse effect of lime-rock mines proposed for excavation in upgradient areas.

The April 2003 tracer test illustrates the difficulty and uncertainty associated with estimates of "interconnected" karst aquifer pore space. Before the test, a scoping effort was conducted to estimate the likely duration of a tracer test and the amount of tracer required in obtaining a peak concentration at the point of recovery that was three to four orders of magnitude greater than the detection limit. Aquifer porosity was assumed to be uniformly distributed, with a potential range between 5 and 40 percent. Before the April 2003 test, these estimates of aquifer effective porosity were regarded as reasonable in the Biscayne aquifer, largely because they were based on the visual inspection of cores, examination of boreholeimage logs, and calculated values of vuggy porosity from these logs (Cunningham et al., 2004a).

An estimation of effective porosity between the points of injection and recovery can be made by applying a simple mass balance for a radially converging flow regime to the rhodamine WT breakthrough data (Javandel et al., 1984),

$$
v=\frac{d r}{d t}=\frac{Q}{(2 \pi r h) n}
$$

where $v$ is mean tracer velocity (m/day); $Q$ is flow rate $\left(\mathrm{m}^{3} /\right.$ day); $r$ is radius from the pumping well $(\mathrm{m}) ; t$ is

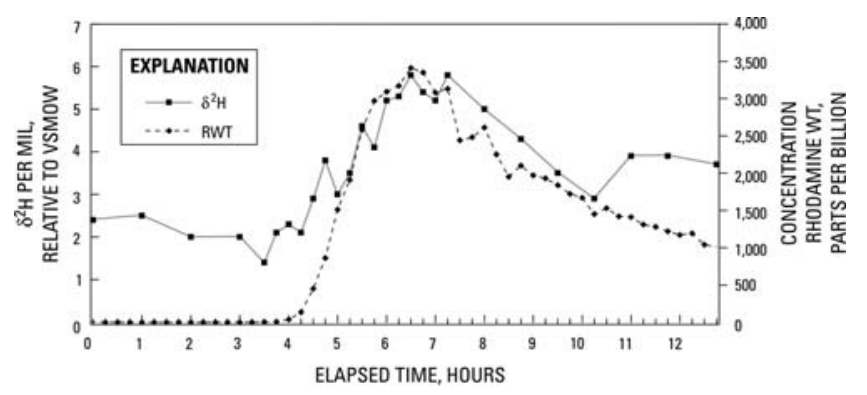

Figure 4. Rhodamine WT (RWT) and deuterium $\left(\delta^{2} \mathrm{H}\right)$ breakthrough curves at production well S-3164 on April 22, 2003.

travel time (days); $h$ is thickness of aquifer (m); and $n$ is effective porosity (dimensionless).

With what is currently known about the heterogeneity of the Biscayne aquifer, Eq. 1 is obviously an oversimplification of the flow regime between the injection and production wells. Implicit in this equation is the assumption of a homogeneous formation, in which ground-water flow is laminar and radially oriented with respect to the production well. Ground-water flow is likely channelized through dissolution-enhanced vuggy features within the Biscayne aquifer, which may constitute a very small percentage of the overall aquifer volume. Nevertheless, Eq. 1 can be used to estimate effective porosity. Therefore, the effective porosity of the aquifer between the injection point and the withdrawal well can be more easily estimated by integrating and rearranging the result:

$$
\begin{aligned}
\int_{0}^{r} r d r & =\int_{0}^{t} \frac{Q}{(2 \pi h) n} d t \\
\frac{r^{2}}{2} & =\frac{Q}{(2 \pi h) n} t \\
n & =\frac{Q}{(\pi h) r^{2}} t
\end{aligned}
$$

where $t$ is the mean time-of-travel between the injection point and the withdrawal well (distance $r$ ).

Using the time to peak rhodamine WT concentration as a conservative assessment of mean arrival time, an effective porosity of about 2 percent is estimated given a withdrawal rate of $43,063 \mathrm{~m}^{3} /$ day $(11,376,000 \mathrm{gal} /$ day), a peak arrival time of 6.5 hours, an aquifer thickness of $18 \mathrm{~m}(59 \mathrm{ft})$ below the base of the low-permeability unit, which is mostly contained in high-frequency cycles HFC $3 b$ and HFC 4 (Figure 3), and an injection- to withdrawal-well distance of $100 \mathrm{~m}$ (328 ft). Effective porosity is estimated to be about 4 percent if thickness is limited only to the 9-m- (29.5-ft-) thick, stratiform, touching-vug pore system (pore class I) that extends below the low-permeability unit mostly contained in highfrequency cycles HFC 3b and HFC 4 (Figure 3). 
In comparison to estimates of aquifer porosity of up to 40 percent from borehole-image logs and core examination, an estimate of 2 to 4 percent from the April 2003 tracer test indicates that movement of ground-water flow is nonuniform in the Biscayne aquifer at the Northwest well field. Dynamic movement of ground water is largely constrained to interconnected pore space contained within stratiform passageways formed by touching vugs. The unexpected rapid breakthrough associated with the April 2003 test provided an opportunity to make adaptive, costeffective changes in the design of the February 2004 colloidal particle test.

The objective of the February and March 2004 tracer tests was to estimate formation properties for specific ground-water flow zones within both shallow and deep parts of the section that included the HFC 2e2, HFC $2 b$, and HFC 2 a units (Figure 3 ). In the shallow ground-water flow zone at the base of high-frequency cycle HFC 2e2, carboxylated polystyrene microspheres and conservative tracers were simultaneously injected using submersible pumps and a single inflatable packer system, which is similar in design to the dual packer Multifunction Bedrock-Aquifer Transportable Testing Tool $\left(\mathrm{BAT}^{3}\right)$ system (Shapiro, 2001). The packer equipment was used to isolate a fluid-filled interval at the bottom of an injection borehole using an inflatable packer; to collect water samples for chemical analysis; to measure hydraulic head; and to inject and withdraw tracers. Transducers and flow meters were linked to a Campbell Scientific CR10X ${ }^{\mathrm{TM}}$ data logger to collect time-varying rate of pumping or fluid-injection and fluid-pressure responses. Data acquisition was integrated using a laptop computer to store and display data in real time. The procedure used to introduce a tracer into the formation consisted of injecting the tracer solution into a packed-off open-hole section of the well followed by flushing a formation water "chaser" to displace residual material from the well into the aquifer. Water samples were collected from the injection well after injection of chaser water had been completed to determine the residual tracer mass that remained within the open-hole injection interval.

In February 2004, deuterium, dissolved sulfur hexafluoride $\left(\mathrm{SF}_{6}\right)$, dissolved halon, and $\sim 2-, \sim 3-$, and $\sim 5$ - $\mu \mathrm{m}$ size microsphere tracers were injected into the G3817 open-hole section, which includes an approximately $0.80-\mathrm{m}-(2.6-\mathrm{ft}-)$ thick, high-permeability ground-water flow zone at the base of high-frequency cycle HFC $2 \mathrm{e} 2$ ( -8.6 to $-10.3 \mathrm{~m}$ or -28 to $-33.8 \mathrm{ft}$ ) (Figure 3 ). Deuterium, halon, $\mathrm{SF}_{6}$, and microsphere breakthrough data currently are being assessed in the context of a comprehensive evaluation of well-field hydraulics. However, preliminary field test data indicate that there has been limited attenuation of microspheres (Harvey et al., 2005), especially where they have advected at high velocities within a touching-vug stratiform flow zone. In
March 2004, a 29-kg (64-lb) sodium bromide (21 kg or $46 \mathrm{lb}$ bromide) tracer was injected into the packed-off open-hole section of injection well G-3816. This well is open, with mostly to highly porous, vuggy rocks of HFC $2 \mathrm{a}$ and HFC $2 \mathrm{~b}$ (Figure 3 ) at a depth of -15.5 to $-19.8 \mathrm{~m}$ $(-50.9$ to $-65 \mathrm{ft})$. Whereas breakthrough data have been obtained from the shallow ground-water flow zone at the base of high-frequency cycle HFC 2e 2 (Figure 3), a tracer pulse was not detected at production well S-3164. Currently, there are no plans to conduct a similar test within this lower zone using deuterium, halon, $\mathrm{SF}_{6}$, or the microspheres. Potential factors that contributed to the inability to detect bromide at production well S-3164 include density differences resulting in downward movement of the tracer, dilution owing to an insufficient tracer mass, and the possibility that diffusive transport exceeds advective transport. Differences of connectivity of touching-vug, stratiform ground-water flow zones could represent a confounding geologic factor. Solutionenlarged burrow and interburrow vugs form a wellconnected pore system of touching vugs in the shallow stratiform ground-water flow zone at the base of HFC $2 \mathrm{e} 2$, but only solution-enlarged burrow molds are well developed within the lower ground-water flow zone in HFC $2 \mathrm{a}$ and HFC $2 \mathrm{~b}$ (Figure 3 ). More vugs observed on the digital borehole-image log are present as separate vugs. Limited horizontal continuity within a lowermost ground-water flow zone in HFC 2a could have further restricted movement of the bromide tracer toward production well S-3164 (Figure 3). The areal extent of touching-vug porosity in the upper part of HFC 2a is limited because that unit is, in part, a coral patch reef.

\section{SUMMARY}

The Northwest well field, Florida's largest municipal well field, is located on the eastern edge of an extractive limestone-rock mining district in north-central MiamiDade County. Mining activities create artificial lakes that are, in places, the same depth as the supply-well production zone. These borrow-pit lakes are within a 247- to 914-m (810- to 3,000-ft) distance of active supply wells. Consequently, there is considerable concern that if mine expansion continues, withdrawals are more likely to be influenced by the quality of lake-mine surface water, and the well field will require use of enhanced disinfection and filtration treatment to remove protozoan pathogens, including Cryptosporidium parvum.

Laboratory and field tests have been coupled to examine potential pathways for solute and microbial contamination, filtration mechanisms that might impede microbial transport, and karst limestone well-field vulnerability issues. Intensive data-collection efforts have been completed and include laboratory column studies, detailed 
geologic site investigations, and hydraulic and field tracer tests. The assessment of some of these data is ongoing.

The Biscayne aquifer underlies the Northwest well field and is formed by vertically repeating assemblages of principally carbonate lithofacies that delineate a cyclostratigraphy. These lithofacies are each characterized by specific pore classes that are characterized by highly permeable, touching-vug stratiform flow zones and uncommon bedding plane vugs (pore class I); lesspermeable matrix with mostly intergranular porosity and separate vugs (pore class II); and leaky, low-permeability layers (pore class III). Most ground-water flow occurs within touching-vug pore space (vuggy pores that coalesce into interconnected pore space), forming tortuous stratiform pathways for advective movement of solutes and pathogens. Diffuse-carbonate flow occurs within matrix-dominated carbonate-rock flow zones, mostly formed by interparticle pore space. Minor, leaky lowpermeability flow characterizes micrite-rich limestone layers that behave, at least locally, as a semiconfining unit.

An underdamped hydraulic response was observed during aquifer tests, reflecting the highly transmissive nature of the Biscayne aquifer. Ground-water occurs under unconfined or semiconfined conditions. Hydraulic tests indicated that the aquifer underlying the Northwest well field is strongly influenced by stage levels in surrounding canals that are at a $2.4-$ to $3.2-\mathrm{km}(1.5-$ to 2.0-mi) distance from supply wells.

Conservative tracers (rhodamine WT and deuterium) were introduced into an injection well located $100 \mathrm{~m} \mathrm{(328}$ $\mathrm{ft}$ ) from a production well in April 2003. Mean velocity of the tracer pulse between the point of injection and recovery (supply well) seems to be one to two orders of magnitude greater than measurements obtained by Miami-Dade County in 1998-99. An assessment of the outcome of a suite of conservative and colloidal tracers (deuterium, halon, $\mathrm{SF}_{6}$, and microspheres) has not been completed. However, preliminary field test data indicate there is limited attenuation of microspheres, especially where they are advected at high velocities within a stratiform ground-water flow zone characterized by touchingvug porosity.

The April 2003 tracer experiment indicated that interconnected pore space or effective porosity of the Biscayne aquifer near the point of injection and the production well is much smaller ( 2 to 4 percent) than previously considered. In the past, researchers simulated ground-water flow and developed time-of-travel well-field protection zones by treating the Biscayne aquifer as a single-porosity, equivalent continuum. On the basis of the 2003 test, however, it seems that specific yield is a poor equivalent measure of the effective porosity required in the continuum models to match field-measured velocities. Effective porosity is one of the formation parameters used to define time-of-travel protection zones.
Although continuum models are well-suited to simulate regional flow conditions, very-near and near-field conditions may compare poorly, especially in a triple-porosity karst aquifer. As a result, there is greater uncertainty with regard to whether physical system complexities and highvelocity, preferential flow conditions within the well field have been correctly approximated.

Comparing the April 2003 tracer test with previous tests is problematic because of differences in test objectives, design, and methods; uncertainties in well construction; well-field operational conditions; climatic and hydrologic conditions; and the distance between the point of injection and recovery (production well). The ability to resolve well-to-well correlative relations and likely pathways for contamination played an important role in the outcome of the 2003 and 2004 tracer tests. Nevertheless, the April 2003 tracer test has demonstrated potential contamination risks in the Northwest well field that are far greater than previously considered, indicating the need for reassessment of existing rock-mine setback distances.

\section{ACKNOWLEDGMENTS}

The authors wish to acknowledge the administrative and field support during the 2003-04 tracer field experiments provided by Julie Baker, Hillol Guha, Theodore Harrison, and Liz Britt of the Miami-Dade Department of Environmental Resources Management and by Clint Oakley, Virginia Walsh, William Pitt, Arthur Baldwin, and other well-field operational staff of the Miami-Dade Water and Sewer Department. John Williams and Alton Anderson of the U.S. Geological Survey provided vertical borehole flow-meter technical support, and Marc Stewart, Dawn Edwards, and Adrian Castillo of the U.S. Geological Survey provided important field assistance during 2003 and 2004 tracer tests. Constructive reviews by Andrew O'Reilly, Ron Reese, Eve Kuniansky, and Sandra Cooper of the U.S. Geological Survey and by three anonymous peer reviewers for the journal helped to improve the final manuscript.

\section{REFERENCES}

Anderson, M. P. And Woessner, W. W., 1992, Applied Groundwater Modeling-Simulation of Flow and Advective Transport: Academic Press, San Diego, CA, 381 p.

BEAR, J., 1993, Modeling flow and contaminant transport in fractured rocks. In Bear, J.; Tsang, C.-F.; and de Marsily, G. (Editors), Flow and Contaminant Transport in Fractured Rock: Academic Press, San Diego, CA, 560 p.

Bredehoeft, J. D.; Cooper, H. H.; and Papadopulos, I. S., 1966, Inertial and storage effects in well-aquifer systems: An analog investigation: Water Resources Research, Vol. 2, pp. 697-707.

Cacas, M. C.; Ledoux, E.; de Marsily, G.; Barbreau, A.; Calmels, P.; Gaillard, B.; AND Margritta, R., 1990a, Modeling fracture flow with a stochastic discrete fracture network: calibration and 
validation-2. The transport model: Water Resources Research, Vol. 26, No. 3, pp. 491-500.

Cacas, M. C.; Ledoux, E.; de Marsily, G.; Tillie, B.; Barbreau, A.; Durand, E.; Feuga, B.; And Peaudecerf, P., 1990b, Modeling fracture flow with a stochastic discrete fracture network: calibration and validation-1. The flow model: Water Resources Research, Vol. 26, No. 3, pp. 479-489.

CAmp, Dresser AND McKee, Inc., 1982, Wellfield Travel Time Model for Selected Well Fields in Dade, Broward, and Palm Beach Counties, Florida: Consultant report for Dade County Department of Environmental and Resources Management, Broward County Planning Council, and Palm Beach County Area Planning Board.

Camp, Dresser And McKee, Inc., 1985, Ground-Water Flow Model for the Northwest Wellfield, Dade County, Florida: Consultant report prepared for Dade County Department of Environmental and Resources Management.

CH2M-HILL, 2001, Risk Assessment and Ground-Water Flow Modeling of the Miami-Dade Northwest Well Field: Consultant report prepared for Miami-Dade County Department of Environmental and Resources Management, $38 \mathrm{p}$.

Cunningham, K. J.; Carlson, J. L.; And Hurley, N. F., 2004a, New method for quantification of vuggy porosity from digital optical borehole images as applied to the karstic Pleistocene limestone of the Biscayne aquifer, southeastern Florida: Journal Applied Geophysics, Vol. 55, No. 1-2, pp. 77-90.

Cunningham, K. J.; Carlson, J. L.; Wingard, G. L.; Robinson, E.; AND WACKeR, M. A., 2004b, Characterization of Aquifer Heterogeneity Using Cyclostratigraphy and Geophysical Methods in the Upper Part of the Karstic Biscayne Aquifer, Southeastern Florida: U.S. Geological Survey Water Resources Investigations Report 03-4208, 66 p.

Cunningham, K. J.; Renken, R. A.; Wacker, M. A.; Robinson, E.; Zygnerski, M. R.; Shapiro, A. M.; And Wingard, G. L., 2006, Application of carbonate cyclostratigraphy and borehole geophysics to delineate porosity and preferential flow in the karst limestone of the Biscayne aquifer, SE Florida. In Geological Society of America Special Paper: Geological Society of America, Boulder, $\mathrm{CO}$, in press.

Cunningham, K. J.; Wacker, M. A.; Robinson, E.; Gefvert, C. J.; And KrupA, S. L., 2004c, Hydrogeology and Ground-water Flow at Levee-31N, Miami-Dade County, Florida, July 2003 to May 2004: U.S. Geological Survey Scientific Investigations Map I2846, 1 plate.

De Marsily, G., 1986, Quantitative Hydrogeology: Academic Press, New York, $440 \mathrm{p}$.

ERSKINE, A. D., 1991, The effect of tidal fluctuation on a coastal aquifer in the UK: Ground Water, Vol. 29, No. 4, pp. 556-562.

Federal Register Notice, October 11, 1979, Vol. 44, No. 198.

Federal Register Notice, May 10, 2000, Vol. 65, No. 91.

Fish, J. E. AND STEWART, M., 1991, Hydrogeology of the Surficial Aquifer System, Dade County, Florida: U.S. Geological Survey Water-Resources Investigations Report 90-4108, 50 p.

GifFIN, D. A. AND WARD, D. S., 1989, Analysis of early-time oscillatory aquifer response. In Symposium on New Field Techniques, National Water Well Association: Dallas, Texas, March 20-23, 1989, pp. 187-211.

GuHA, H., 2005, personal communication, Miami-Dade Department of Environmental Resources Management, Miami, FL.

Guha, H.; KottKe, H.; And Harrison, T., 2003, Dye tracer study near a high capacity public supply well system, Miami-Dade County, Florida, U.S.A. In Proceedings, 2003 International Water Congress: American Water Resources Association, Middleburg, VA, pp. 1-9.

Harvey, R. W. and Garabedian, S. P., 1991, Use of colloid filtra- tion theory in modeling movement of bacteria through a contaminated sandy aquifer: Environmental Science Technology, Vol. 15, No. 1, p. 178-185.

Harvey, R. W.; Metge, D. W.; Shapiro, A. M.; Renken, R. A.; Osborn, C. L.; RYAN, J. N.; AND CUNNINGHAM, K. J., 2005, Use of carboxylated polystyrene microspheres to assess the transport potential of Cryptosporidium parvum öocysts in karstic limestone of the Biscayne Aquifer (Northwest Well Field, Miami, FL): American Chemical Society, 229th ACS National Meeting, March 13-17, 2005, San Diego, CA: Electronic document, available at http:// oasys2.confex.com/acs/229nm/techprogram/P816823.HTM

JACKSON, J. A. (Editor), 1997, Glossary of Geology, 4th ed.: American Geological Institute, Alexandria, VA, $769 \mathrm{p}$.

Javandel, I.; Doughty, C.; AND Tsang, C.-F, 1984, Groundwater Transport-Handbook of Mathematical Models: Water Resources Monograph Series 10, American Geophysical Union, Washington, DC, $228 \mathrm{p}$.

Kerans, C. And Tinker, S. W., 1997, Sequence Stratigraphy and Characterization of Carbonate Reservoirs: SEPM Short Course Notes 40, Society for Sedimentary Geology, Tulsa, OK, $130 \mathrm{p}$.

KotTKe, H. AND Harrison, T., 2005, personal communication, MiamiDade Department of Environmental Resources Management, Miami, FL.

KRUPA, S., 2005, personal communication, South Florida Water Management District, West Palm Beach, FL.

Krupa, S.; Hill, S.; AND Bevier, C., 2001, Miami-Dade County Northwest Well Field Groundwater Velocity Investigation: Technical Publication WS-1, South Florida Water Management District, $36 \mathrm{p}$.

Lohman, S. H., 1972, Ground-Water Hydraulics: U.S. Geological Survey Professional Paper 708, 70 p.

LuCiA, F. J., 1995, Rock-fabric/petrophysical classification of carbonate pore space for reservoir characterization: American Association Petroleum Geologists Bulletin, Vol. 79, p. 1275-1300.

LuCIA, F. J., 1999, Carbonate Reservoir Characterization: SpringerVerlag, New York, 226 p.

Macler, B. A. And Merkle, J. C., 2000, Current knowledge on groundwater microbial pathogens and their control: Hydrogeology Journal, Vol. 8, pp. 29-40.

Martin, J. B. And Screaton, E. J., 2001, Exchange of matrix and conduit water with examples from the Florida aquifer. In Kuniansky, E. L. (Editor), U.S. Geological Survey Karst Interest Group Proceedings, St. Petersburg, Florida, February 13-16, 2001: U.S. Geological Survey Water-Resources Investigations Report 01-4011, pp. 38-44.

Merritt, M. L., 1996, Numerical Simulation of a Plume of Brackish Water in the Biscayne Aquifer Originating from a Flowing Artesian Well, Dade County, Florida: U.S. Geological Survey Water-Supply Paper 2464, 74 p.

Metropolitan Dade County, 1980, Protection of Potable Water Supply Wells Program: Department of Environmental Resource Management Technical Report 80-4, 176 p.

Metropolitan Dade County, 1981, Resolution No. R-81-23 Adopting the Northwest Well Field Time-of Travel Protection Zones: Board of County Commissioners, Metropolitan Dade County, Miami, FL.

Metropolitan Dade County, 1983, Resolution No. R-83-82 Adopting the 30-Day Zone, 40-Ft Depth Rock-Mine Setback Limitation: Board of County Commissioners, Metropolitan Dade County, Miami, FL.

Metropolitan Dade County, 1985a, Resolution No. R-85-54, Adopting an Additional 30-Day Rock-Mine Setback Distance: Board of County Commissioners, Metropolitan Dade County.

Metropolitan Dade County, 1985b, Resolution No. R-1541-85, 
Adopting the Northwest Well Field Protection Plan: Board of County Commissioners, Metropolitan Dade County, Miami, FL.

Miami-Dade Departmentof Environmental Resources Management, 1999, Description and Analysis of Preliminary Tracer Trials Conducted at the Northwest Wellfield, Miami-Dade County, Florida: Report, Miami-Dade Department of Environmental Resources Management, $16 \mathrm{p}$.

Miami-Dade Departmentof Environmental Resources Management, 2000a, Description and Analysis of Full-Scale Tracer Trials Conducted at the Northwest Well Field, Miami-Dade County, Florida: Report, Miami-Dade Department of Environmental Resources Management, $20 \mathrm{p}$.

Miami-Dade Department of Environmental Resources ManageMENT, 2000b, Northwest Well Field Watershed Protection Plan: Report prepared for the South Florida Water Management District, Miami-Dade Department of Environmental Resources Management.

National Research Council, 1993, Ground Water Vulnerability Assessment-Predicting Relative Contamination Potential under Conditions of Uncertainty: National Academy Press, Washington, DC, $224 \mathrm{p}$.

National Research Council, 1996, Rock Fractures and Fluid Flow: Contemporary Understanding and Applications: National Academy Press, Washington, DC, $551 \mathrm{p}$.

Osborn, C. L.; Ryan, J. N.; Harvey, R. W.; Metge, D. W.; LandKamer, L. L.; Renken, R. A.; Cunningham, K. J.; And Shapiro, A. M., 2004, Transport and attachment of Cryptosporidium parvum öocysts and microsphere analogs in karstic limestone of the Biscayne aquifer, Miami-Dade County, Florida: Eleventh International Symposium on Water Rock Interaction, Saratoga Springs, NY, 2 p.

Parker, G. G.; Ferguson, G. E.; And Love, S. K., 1955, Water Resources of Southeastern Florida, with Special Reference to the Geology and Ground Water of the Miami Area: U.S. Geological Survey Water-Supply Paper 1255, 965 p.

Perkins, R. D., 1977, Depositional framework of Pleistocene rocks in south Florida. In Enos, P. and Perkins, R. D. (Editors), Quaternary Sedimentation in South Florida, Part II: Geological Society of America Memoir 147, Geological Society of America, Boulder, CO, pp. 131-198.

Prickett, T. A. And Lonnquist, C. G., 1971, Selected Digital
Computer Techniques for Groundwater Flow Modeling: Illinois State Water Survey Bulletin No. 55, 62 p.

Reeves, M.; Freeze, G. A.; Kelley, V. A.; Pickens, J. F.; Upton, D. T.; And Davies, P. B., 1991, Regional Double-Porosity Solute Transport in the Culebra Dolomite under Brine-ReservoirBreach Release Conditions: An Analysis of Parameter Sensitivity and Importance: Report SAND89-7069, Sandia National Laboratories, $243 \mathrm{p}$.

Schroeder, M. C.; Klein, H.; AND Hoy, N. D., 1958, Biscayne Aquifer of Dade and Broward Counties, Florida: Florida Geological Survey Report of Investigations No. 17, 56 p.

SHAPIRO, A. M., 1989, Interpretation of oscillatory water levels in observation wells during aquifer tests in fractured rock: Water Resources Research, Vol. 25, No. 10, pp. 2129-2137.

ShapiRo, A. M., 2001, Characterizing Ground-Water Chemistry and Hydraulic Properties of Fractured Rock Aquifers Using the Multifunction Bedrock-Aquifer Transportable Testing Tool $\left(B A T^{3}\right)$ : U.S. Geological Survey Fact Sheet FS-075-01.

Vacher, H. L. ANd Mylroie, J., 2002, Eogenetic karst from the perspective of an equivalent porous medium: Carbonates Evaporites, Vol. 17, No. 2, pp. 182-196.

van Genuchten, M. T. And Wierenga, P. J., 1976, Mass transfer studies in sorbing porous media, I. Analytical solutions: Soil Science Society America Journal, Vol. 40, pp. 473-481.

WALKER, F. R. AND STEDINGER, J. R., 1999, Fate and transport model of Cryptosporidium: Journal Environmental Engineering, Vol. 125, No. 4, pp. 325-333.

Walters, R. R., 1987, Dade County, Case Study. In Page, G. W. (Editor), Planning for Ground Water Protection: Academic Press, Orlando, FL, pp. 205-239.

Wilsnack, M. M.; Welter, D. E.; Nair, S. K.; Montoya, A. M.; Zamorano, L. M.; Restrepo, J. I.; And Obeysekera, J., 2000, North Miami-Dade County Ground Water Flow Model: Report, South Florida Water Management District, 40 p.

Wilson, J. T.; Mandell, W. A.; Paillet, F. L.; Bayless, E. R.; Hanson, R. T.; Kearl, P. M.; Kerfoot, W. B.; Newhouse, M. W.; AND Pedler, W. H., 2001, An Evaluation of Borehole Flowmeters used to Measure Horizontal Ground-Water Flow in Limestones of Indiana, Kentucky, and Tennessee, 1999: U.S. Geological Survey Water Resources Investigations Report 01-4139, 129 P. 